\title{
PENGARUH ERA MEDIA BARU DAN TERJADINYA CHAOS IDENTITAS
}

\author{
Endang Tri Irianingsih \\ Universitas Sebelas Maret, Surakarta, Indonesia \\ eryankusuma@gmail.com \\ Bani Sudardi \\ Universitas Sebelas Maret, Surakarta, Indonesia \\ banisudardi@yahoo.com \\ Wakit \\ Universitas Sebelas Maret, Surakarta, Indonesia \\ abdullahwakit@yahoo.com
}

\begin{abstract}
Identity is a typical characteristic of an individual distinguishing him/her from others. Identity creation is affected by such factors as environment. Modernization age also contributes to creating identity, characterized with information technology sophistication. Information technology sophistication has led human beings to enter into new media era by presenting Smartphone. However, the presence of smartphone has contributed to the creation of false (counterfeit) identity. This article reveals the effect of smartphone on identity creation that can result in chaos. The problems addressed were (1) what does identity chaos mean? (2) what is the effect of new media era on identity creation? (3) how to anticipate identity chaos in new media era? The conclusions drawn in this article were that: Identity chaos is a condition in which there is identity falsity as a result of social paradox and moral degradation. The effect of new media era with the presence of smartphone leads people to be entrapped in simulacra. Identity reinforcement should be conducted by making true representation corresponding to our identity through creating social spaces and limiting the smartphone use.
\end{abstract}

keywords: new media, lifestyle, chaos, identity, simulacra

\begin{abstract}
ABSTRAK
Identitas adalah ciri khas dari seorang individu yang membedakan dengan yang lain. Pembentukan identitas dipengaruhi berbagai faktor. Modernisasi berperan dalam pembentukan identitas melalui teknologi informasi. Teknologi informasi telah membawa orang memasuki era media baru, misalnya kehadiran smartphone. Namun, smartphone telah mempengaruhi konstruksi identitas yang palsu. Artikel ini mengungkapkan pengaruh smartphone terhadap pembentukan identitas, yang diasumsikan menimbulkan chaos. Permasalahan yang dibahas adalah (1) apa yang dimaksud dengan chaos identitas?, (2) bagaimana pengaruh era media pada pembentukan identitas?, dan (3) bagaimana mengantisipasi chaos identitas pada era media baru?. Chaos identitas adalah "kepalsuan" identitas sebagai akibat dari paradoks sosial dan degradasi moral. Pengaruh era media baru, misal smartphone, membuat orang terjebak dalam simulacra. Sebagai benteng pertahanan chaos identitas, penguatan identitas perlu dilakuakn dengan representasi sesuai identitas yang nyata dalam membangunruang sosial dan membatasi penggunaan smartphone.
\end{abstract}

Kata kunci: Media Baru, gaya hidup, chaos, identitas, simulakra 


\section{PENDAHULUAN}

Manusia diciptakan sebagai makhluk individu dan makhluk sosial. Manusia sebagai makhluk individu berhak untuk memenuhi kebutuhan individu demi kelangsungan hidupnya. Sebagai makhluk sosial, dia juga memiliki kebutuhan, misalnya berhubungan dengan manusia yang lain dalam bentuk interaksi sosial.

Interaksi sosial telah
mengalami perubahan karena perkembangan zaman seperti era modern. Sebelum abad ke-20, komunikasi dilakukan dengan pertemuan-pertemuan secara langsung, melalui tatap muka. Bahkan jarak yang jauh ditempuh meski hal itu membutuhkan waktu yang lama. Interkasi sosial terbangun secara intens antar tetangga. Satu sama lain sering bertegur sapa, saling bertemu dan membantu, dan memiliki nilainilai komunal.

Perubahan drastis terjadi ketika memasuki abad ke-21. Abad ini, dunia banyak mengalami perubahan terutama disebabkan perubahan zaman modern yang ditandai dengan kemajuan teknologi, termasuk cara berkomunikasi. Teknologi telah menjadi gaya hidup.
Komunikasi semakin mudah dengan adanya telepon. Kemajuan teknologi salah satunya memunculkan alat yang bernama smartphone, atau lebih sering dikenal dengan telepon genggam. Alat ini dilengkapi aplikasi seperti komputer sehingga semakin memudahkan komunikasi. Smartphone merupakan alat komunikasi manusia pada zaman modern dengan memanfaatkan kecanggihan teknologi internet. Akibatnya, kemudahan menjadi pilihannya.. Adanya jaringan internet dalam alat komunikasi ini membuat orang lebih mudah untuk menyelesaikan permasalahan, seperti saat menggunakan komputer. Pada jaman sekarang, jika seseorang ingin bertemu atau sekedar bertegur sapa dengan saudara atau teman jauh, hal itu cukup dilakukan melalui aplikasi pada smartphone. Saat itu, jarang orang bertemu untuk sekedar melakukan interaksi sosial walau dia hanya berbicara. Mereka lebih memilih menggunakan berbagai aplikasi media sosial yang ada di smartphone.

Keberadaan smartphone ini mampu menciptakan ruang sosial. Menurut Lubis, ruang sosial adalah 
ruang kelompok-kelompok status yang dicirikan oleh berbagai gaya hidup yang berbeda (2014, h.120). Hal ini yang menjadi fokus perhatian dalam artikel ini. Hal yang dibahas diantaranya adalah pengaruh smartphone dalam era media baru yang telah membawa perubahan dalam interaksi sosial. Hal itu secara tidak sadar telah mempengaruhi pembentukan identitas seseorang.

\section{TEORI DAN METODOLOGI}

Proses perubahan komunikasi telah merubah gaya hidup masyarakat. Kini, komunikasi telah masuk pada era media baru yaitu smartphone. Smartphone awalnya merupakan media komunikasi yang berasal dari revolusi telepon genggam. Komunikasi telah menjadi kebutuhan hidup manusia. Sebab, manusia adalah makhluk sosial yang perlu berinteraksi dengan orang lain. Interaksi sosial adalah wujud manusia bersosialisasi dalam komunitas. Seseorang selalu berhubungan dengan orang lain. Sebagai akibatnya, hal itu memerlukan ruang untuk bersosialisasi.
Pengaruh smartphone mulai meluas. Sebagai contohnya adalah para pekerja di kota, baik mereka yang berasal dari arus urbanisasi. Orang-orang urban ini, ketika pulang ke kampung halaman, mulai mengenalkan gaya hidup orang perkotaan. Maka, hal yang muncul adalah istilah orang kampungan sebab mereka meniru gaya hidup orang kota. Faktor inilah yang menjadikan smartphone kemudian mulai masuk di desa-desa dengan mudah dan menjadi tren tersendiri. Sebagai akibatnya, hal ini pun berubah menjadi budaya popular.

Budaya popular telah menjadi bagian hidup masyarakat era kapitalisme sekarang ini. Segala sesuatu diproduksi secara massa dan seragam. Pasar dikondisikan seragam. Para konsumen terbawa pada kenikmatan-kenikmatan palsu dalam mengkonsumsi. Pembelian suatu barang tidak lagi didasarkan pada kebutuhan melainkan pada hasrat semata. Hal ini terutama pada era media baru ini yang segala sesuatu dapat di lihat dari genggaman melalui aplikasi smartphone.

Metode yang digunakan dalam penelitian ini adalah metode 
fenomenologi. Data diperoleh dari observasi. Data yang digunakan adalah data kualitatif. Sampel yang dilihat adalah tiga jenis kelompok sosial, yakni pelajar, pekerja, dan ibu rumah tangga. Interpretasi data dilakukan sesuai dengan prosedur dalam kajian budaya, terutama pada fenemologi sebagai acuan interpretasi.

\section{HASIL DAN PEMBAHASAN}

Penggunaan Smartphone di Lapisan

\section{Masyarakat}

Berdasarkan hasil observasi, beberapa fenomena terjadi di masyarakat terkait penggunaan teknologi ini. Fenomena ini adalah realitas dari penggunaan smartphone yang terjadi di masyarakat. Masyarakat terdiri atas berbagai lapisan. Penelitian ini kemudian difokuskan pada tiga lapisan masyarakat. Ketiga lapisaan itu adalah pelajar, pekerja, dan ibu rumah tangga. Mereka memiliki peran aktif dalam penggunaan smartphone. Mereka memiliki daya dukungnya.

Hasil observasi itu mengungkapkan bahwa kalangan pelajar sangat sering menggunakan smartphone baik untuk komunikasi atau mengaktifkan media sosial. Namun, mereka cenderung menggunakan smartphone dengan merk tertentu. Mereka terbius harga mahal, tetapi tidak mengetahui kegunaannya. Mereka hanya sekedar menggunakan smartphone untuk foto dan mengakses media sosial. Pada kalangan pekerja, keberadaan smartphone sangat diperlukan karena menjadi suatu kebutuhan untuk melakukan komunikasi. Namun, ada juga yang menggunakan untuk mengakses media sosial. Fenomena yang lebih menarik adalah penggunaan smartphone pada kalangan ibu rumah tangga. Fungsi utama smartphone adalah untuk eksistensi.

\section{Identitas dan Chaos Identitas}

Individu membentuk identitas sesuai dengan yang menjadi karakter dan sifatnya. Identitas mencirikan seseorang. Dia menjadi pembeda dari orang lain. Identitas ke-Indonesia-an, misalnya, diperlihatkan dengan rasa nasionalisme, misal membuat ungkapan-ungkapan nuansa nasionalisme, menjadi negarawan yang handal, turut aktif dalam kegiatan-kegiatan yang bertemakan nasionalisme, dan sebagainya.

Identitas dipengaruhi oleh faktor-faktor eksternal, terutama 
pada ruang sosial. McCarthy yang menjelaskan pemikiran Habermas mengatakan bahwa ketika terjadi krisis yang mengancam, integrasi sosial dapat merongrong landasan interaksi social. Hal itu juga menciptakan jebakan identitas individu. Sebagai konsekuensinya, identitas individu terbelenggu atas permasalahan-permasalahan sistem yang tidak terpecahkan. Individu terjebak dalam proses yang ditakdirkan (2006, h.472-473).

Ruang sosial yang memberikan konstruks identitas perlu diperhatikan. Sebab, identitas dibentuk dari luar individu itu. Hal itu menunjukkan sebuah identitas yang berubah-ubah. Sebagai konsekuensinya, hal tersebut akan menciptakan identitas yang kabur bagi seorang individu. Menurut Ida, identitas juga dipengaruhi oleh tradisi budaya. Keadaan itu ditunjukkan dengan pembentukan makna budaya (cultural meaning). Pemaknaan budaya merepresentasikan identitasidentitas kultural masyarakatnya (2014, h.55).

Mereka lupa terhadap realitas hidup yang sebenarnya. Sebab, mereka telah hidup di dunia maya, dalam dunia hiperealitas. Ketika lingkungan sudah banyak muncul degradasi moral, hal yang akan terjadi adalah paradoks moral. Hal ini disebut sebagai chaos. Chaos merupakan kondisi dalam mana telah terjadi suatu keadaaan yang bertentangan dengan nilai dan norma dalam masyarakat. Sebagai akibat dari hal itu dapat memicu suatu konflik.

Pengertian chaos identitas adalah suatu kondisi dalam mana seorang atau individu memiliki identitas yang kabur. Identitas tersebut berbenturan dengan identitas yang real. Paradoks moral merupakan efek dari keinginan mengimitasi suatu citra tertentu menurut bayangannya.

Berdasarkan sampel yang diteliti diperoleh bahwa identitas yang ditampilkan antara di dunia maya dan dunia nyata adalah sesuatu berbeda. Mereka mayoritas menampilkan suatu pencitraan. Citra diri yang dikonstruksi adalah citra bayangan yang mereka inginkan. Tujuan mereka adalah mencari popularitas dan kesenangan. Sebab, sebagaian dari mereka menginginkan 
pujian atau komentar dari pengguna dunia maya lain.

\section{Pengaruh Era Media Baru Pada} Pembentukan Identitas

Komunikasi memang berkaitan dengan kehidupan manusia, tidak dapat dipisahkan. Cara berkomunikasi, pertama, adalah menggunakan alat bicara dengan bersuara. Hal ini memunculkan komunikasi melalui pembicaraan. Kemudian, hal itu berkembang saat manusia dapat menggunakan tanda, seperti tulisan. Pada awalnya, tulisan atau surat dikirim menggunakan burung merpati sehingga dinamakan merpati pos.

Pada masa kerajaan, surat dikirimkan melalui kurir kerajaan yang harus menempuh jarak yang jauh dan waktu yang lama. Kemudian, memasuki masa penjajahan, kebiasaan dan tradisi itu diterima di Indonesia. Para penjajah membawa pengaruh yang cukup signifikan pada perubahan alat komunikasi di Indonesia.

Pada masa berikutnya, ada penggunaan radio, televisi, dan surat kabar untuk penyebarluasan informasi dan komunikasi. Pada masa perang, penjajah menggunakan telegraf, telepon, dan telegram untuk mengkomunikasikan pesan jarak jauh. Selanjutnya, masyarakat terjajah mulai mengenal teknologi komunikasi tersebut, meski masih terbatas. Orang-orang tertentu saja dapat menggunakannya. Telepon pada masa ini adalah telepon kabel dan menjadi gaya hidup para priyayi, bangsawan, dan keluarga raja. Rakyat biasa tidak dapat menjangkaunya karena pada masa penjajahan rakyat banyak mengalami keterpurukan akibat penjajahan.

Namun, kehidupan masyarakat pada masa ini justru menunjukkan nilai-nilai komunal yang masih kuat. Interaksi sosial terbangun satu sama lain. Mereka seakan menjadi seperti saudara karena ada juga rasa senasib.

Setelah masa penajajahan berlalu, alat komunikasi yang berkembang adalah telepon kabel. Telepon kabel mengalami perubahan bentuk sampai pada gagang telepon yang tidak menggunakan lilitan kabel. Hal ini dicirikan dengan tombol tekannya sehingga dapat digunakan lebih dari dua meter.

Sementara itu, di dunia Barat, teknologi berkembang dengan maju 
pesat. Hal ini disebabkan revolusi industry. Selanjutnya, revolusi industri itu mulai mempengaruhi negara-negara berkembang seperti Indonesia. Teknologi informasi juga turut dikembangkan dari telepon rumah tanpa kabel menjadi adanya pager. Pager adalah alat komunikasi yang dapat digunakan untuk mengirimkan pesan jarak jauh. Pager juga menjadi gaya hidup masyarakat Indonesia yang tinggal di kota. Jika sebelumnya para ningrat dan priyayi memiliki gaya hidup tertentu dalam berkomunikasi, kini memasuki abad ke-19, gaya hidup merupakan bagian dari kebiasaan masyarakat perkotaan. Sebab, hal ini didukung oleh pusat pertumbuhan ekonomi dan pembangunan.

Masa modern mulai merambah Indonesia menjelang abad ke-20. Teknologi mulai masuk Indonesia melalui proses "westernisasi" yang sangat masif. Pengaruh-pengaruh dunia Barat sangat terlihat terhadap perubahan gaya hidup orang-orang Indonesia. Setelah pager muncul, alat komunikasi berkembang menjadi telepon genggam (handphone), yang berukuran relatif besar.
Proses perubahan komunikasi juga merubah gaya hidup masyarakat. Meskipun hal itu pada mulanya baru terjadi di lingkungan perkotaan, pada masa ini, televisi dan radio sudah mulai "menjamur" sampai desa-desa. Kalangan tertentu memiliki fasilitas ini. Di saat masyarakat kota memiliki gaya hidup melalui alat komunikasi telepon gengam, masyarakat desa sebatas pada penggunaan televisi.

Pengaruh pengunaan telepon gengam mulai meluas ketika para pekerja yang ada di kota kembali ke desa asalnya. Orang-orang ini ketika pulang ke kampung mulai mengenalkan gaya hidup orang perkotaan. Sebagai akibatnya, ada stilah orang kampungan, yakni bagi mereka yang tidak dapat bergaya hidup seperti orang kota. Faktor inilah yang menjadikan telepon gengam mulai masuk di desa-desa. Selanjutnya, hal itu menjadi tren tersendiri meski yang memilikinya sebatas kalangan tertentu. Sebab, persoalan ekonomi menjadi bagian yang tidak bisa dipisahkan.

Me masuki abad ke-21 yang serba kapitalis, keadaan ini merupakan masa kejayaan para kaum 
pemilik modal dan persaingan mulai terjadi. Handphone yang dulu merupakan barang mewah sekarang menjadi barang "kacangan". Sebab, semua orang dapat menjangkau dan memilikinya. Bahkan, masa sekarang, telepon gengam menjelma menjadi smatphone yang dapat digunakan untuk berselancar di dunia maya. Hal ini juga menjadi gaya hidup anak kecil, remaja, hingga dewasa.

Pada masa ini, komunikasi lebih mudah dilakukan meski jarak membentang. Untuk berkomunikasi, hal itu tidak perlu menggunakan banyak waktu karena sekali tekan atau sentuh pada layar smartphone, komunikasi langsung terjadi. Dunia bisnis juga tidak perlu terhambat karena penggunaan smartphone. Sebab, berbagai kemudahan dapat terwujud, seperti mengirimkan surat elektronik melalui gengaman tangan. Keberadaan smartphone ini juga turut mempopulerkan penggunaan surat elektronik, yang dulu masih mengunakan jasa pengiriman lewat pos. Surat elektronik merupakan cara pengiriman pesan menggunakan internet.

Para produsen bersaing untuk memproduksi smartphone.
Konsekuensinya, persaingan harga menjadi tidak dapat dihindarkan dan semua masyarakat dapat menjangkaunya. Semua masyarakat dapat memiliki fasilitas dan kualitas dari smartphone seperti fitur yang bersaingan dengan aharga jualnya. Hal ini justru menjadi keuntungan bagi konsumen kelas bawah yang dapat menikmati smartphone meskipun tidak secanggih yang harganya mahal. Namun, sayangnya, penggunaan teknologi pada smartphone ini tidak diimbangi dengan kesadaran penggunaan teknologi informasi. Sebagai akibatnya, banyak kejahatan muncul melalui media ini.

Ruang sosial saat ini sendiri telah mengalami perubahan. Jika dulu ruang sosial berbentuk pertemuan langsung antar individu dengan bertatap muka, kini ruang sosial sudah berpindah dengan grup-grup media sosial yang ada. Ruang sosila itu kini berada dalam gengaman tangan atau smartphone. Interaksi sosial sangat mudah dilakukan. Sebab, hal itu dilakukan dengan cara cukup menuliskan pesan dalam grup, pesan itu akan banyak ditanggapi teman-teman satu grup. 
Meskipun demikian, interaksi ini juga memang masih ada yang melakukan pertemuan secara langsung. Namun, hal itu jarang dilakukan. Umumnya, pertemuan tersebut diawali dengan pertemuan di dunia maya terlebih dulu. "Percepatan teknologi komunikasi telah melemparkan peradaban baru kehidupan manusia yang dibentuk oleh karateristik media baru" (Budiawan, 2015, h.5).

Teknologi yang semakin canggih membuat hidup manusia semakin mudah termasuk dalam berkomunikasi karena meskipun jarak jauh dapat dengan mudah berinteraksi. Selain dampak positif tersebut, teknologi komunikasi juga membawa dampak negatif pada komunikasi khususnya pada interaksi sosial.

Kemudahan yang diperoleh dari kecanggihan media sosial membuat orang enggan melakukan interaksi dengan orang lain. Mereka lebih senang bersosialisasi melalui media sosial yang ada di smartphone. Fiturfitur yang disediakan dalam smartphone membuat pemiliknya "berada dalam dunianya sendiri". Mereka cenderung menyibukkan diri dengan sesuatu yang ada di genggamannya. Lama-kelamaan, perilaku tersebut mengubah kebiasaan mereka. Sangat dimungkinkan, mereka akan menjadi makhluk individualistis atau a-sosial. Hal yang terjadi adalah tidak lagi ada saling bertegur sapa atau sekedar berbicara dengan teman di samping tempat duduknya. Sebab, mereka sudah sibuk dengan "dunianya sendiri, yang berada di smartphone. Peursen mengatakan bahwa "dalam dunia mitis, manusia belum merupakan seorang pribadi yang bulat dan utuh" (1988, h. 02). Maka, representasi yang dibangun antara dunia nyata dan dunia maya haruslah seimbang untuk menunjukkan jati diri. Namun, era sekarang terjadi sebaliknya. Representasi antara dunia nyata dan dunia maya mengalami jurang perbedaan. Mereka telah masuk dalam dunia simulacrum yang mereka buat. Mereka membentuk citraan-citraan yang palsu atau melalui tiruan pada seseorang (Lubis, 2014, h.180).

Identitas palsu yang dibentuk ini merupakan pengaruh ideologi yang dianut. Menurut Poepowardojo dan Alexander Seran, “ideologi 
mengkondisikan kesadaran palsu tentang realitas, yang hakikinya merupakan kesadaran yang bersifat sosial menjadi kesadaran yang besifat subjektif", (2016, h.74). Suatu realitas dalam dunia sosial saat ini adalah hiper-realitas sosial.

Pada dunia hiper-realitas ini, identitas telah melebur menjadi satu antara yang real dan yang hiper-real. Perkembangan teknologi menjadi unsur penting dalam berkomunikasi di era hiper-realitas ini. Hal ini kemudian membentuk sebagai cyberculture. Cyberculture adalah efek dan perubahan sosial pada masyarakat yang terjadi karena pengaruh teknologi terutama teknologi internet (Ida, 2014, h.56). Masyarakat sekarang berkembang dengan budaya yang bertumpu pada teknologi. Sebagai contoh, komunikasi banyak dilakukan menggunakan internet dalam dunia maya.

Frissen et.al.

mengkategorikan bahwa orang-orang yang asyik dengan media teknologi disebut dengan homo ludens. Homo ludens adalah golongan atau kelompok orang yang suka terhadap permainan. Permainan dalam teknologi ini membentuk identitasnya. Identitas bagi homo ludens adalah identitas yang diperoleh melalui proses ludifikasi atau bermain. Permainan itu berdasarkan aturan yang sudah ada sebelumnya.

Permainan ini menimbulkan kesenangan dan sulit untuk ditinggalkan. Sebagai akibatnya, hal itu akan menjadi gaya hidup. Smartphone saat ini telah menjadi gaya hidup bagi orang-orang modern yang membentuk identitas mereka. Hal itu bukan hanya karena fitur-fitur yang ada dalam smartphone, tetapi saat ini mereka sudah gila merk. Pemilik smartphone dengan merk mahal saat ini tidak hanya dimiliki bagi mereka yang sudah berpenghasilan saja, tetapi kebanyakan juga dimiliki para pelajar dan ibu rumah tangga. Mereka menggunakan merk tertentu tidak sekedar kecanggihan fitur di dalamnya, tetapi lebih pada prestise atau penghargaan orang lain terhadap dirinya. Bagi pengguna merk tertentu, hal tersebut menambah rasa percaya diri. Mereka mengganggap dirinya telah menjadi kaum kelas atas. Kini merk 
smartphone yang digunakan telah dianggap dapat menentukan kelas sosial mereka.

Merk dengan harga yang mahal atau tinggi dimiliki oleh kalangan atas. Kalangan atas adalah mereka yang memiliki kekayaan dalam jumlah banyak. Namun, di balik merk-merk tersebut, keberadaan smartphone yang berpotensi menjadi gaya hidup telah membawa budaya atau kebiasaan baru pada masyarakat. Mereka telah terjebak pada budaya konsumen (consumer culture).

Featherstone menjelaskan bahwa "pada budaya konsumen, konsumsi tidak harus dipahami sebagai konsumsi nilai manfaat, suatu keperluan material, tetapi terutama sebagai konsumsi tanda" (2008, h.202). hal ini menegaskan bahwa tidak peduli kalangan atas atau bawah. Baginya, mereka sekarang ini harus memiliki smartphone terbaru yang baru rilis. Harga yang bersaing antar merk membuat kalangan bawah dapat menikamati smartphone premium dengan kualitas bagus dan mirip seperti yang dimiliki kalangan atas. Produksi massal smartphone ini merupakan bagian dari budaya popular.

Ciri budaya popular ada empat, yakni banyak disukai orang, jenis kerjaan rendahan, untuk menyenangkan orang, dan budaya yang dibuat untuk diri sendiri (Raymond Williams dalam Lubis, 2015, h.71). Smartphone merupakan jelmaan dari handphone yang dulu masih menggunakan tombol dan diproduksi dalam jumlah terbatas.

Namun, seiring perkembangan zaman dan kemajuan teknologi, hal itu berubah menjadi smartphone dengan layar sentuh. Selanjutnya, smartphone diproduksi dalam jumlah banyak untuk memenuhi kebutuhan pasar bagi segala lapisan masyarakat. Produksi smartphone ini dapat berbagai jenis merk. Akibatnya, hal ini dapat dijangkau semua kalangan. Bahkan, ada juga yang merupakan tiruan merk terkenal secara bentuk tetapi fitur berbeda. Produsen tidak ingin kehilangan setiap jenjang pangsa pasar sehingga mereka melakukan hal ini. Maka, hal itu tidak heran apabila pelajar sekarang ini dapat memegang smartphone yang bermerk dan berharga mahal 
meskipun kualitas barangnya berada di bawah produk utama.

Setelah smartphone menjadi gaya hidup, hal itu didukung dengan fitur-fitur yang ditawarkan di dalamnya. Sayangnya, hal itu menyebabkan tidak semua pengguna dapat menggunakannya. Sebab, mereka membeli hanya untuk memenuhi tuntutan gaya hidup. Mereka umumnya mencontoh gaya hidup dari para selebritas di ibukota.

Sebagai contohnya adalah kelompok ibu rumah tangga. Ibu rumah tangga yang banyak mengkonsumsi kehidupan selebritas melalui tayangan televisi banyak yang meniru. Mereka tidak jarang bertingkah layaknya sang idola. Para selebritas ibu kota telah dianggap sebagai kalangan atas karena gaya hidup mewahnya. Maka, untuk menjadi kalangan atas, mereka akan meniru gaya selebritas.

Hal ini merupakan identitas yang dibentuk secara simbolis karena imitasi. Akhirnya, smartphone dalam genggamannya hanya digunakan untuk mengakses media-media sosial dan toko-toko online untuk memenuhi kebutuhan gaya hidup mereka. Hal tersebut dilakuakn agar seperti para selebritas. Keadaan yang demikian ini memiliki dampak pada pembentukan identitas diri. Maka, pada era media baru saat ini, tidak hanya lingkungan keluarga, tetangga, ataupun sekolah dan tempat kerja saja yang ikut andil mempengaruhi identitas, kecanggihan teknologi juga memiliki peranan dalam mempengaruhi identitas.

\begin{tabular}{ll}
\multicolumn{2}{c}{ Identitas maya yang } \\
ditampilkan dalam dunia maya \\
mayoritas berbeda dengan dunia
\end{tabular}
nyata. Maka, hal itu juga bisa disebut sebagai identitas palsu. Namun, sayangnya, kebanyakan dunia maya dibawa ke dalam dunia nyata. Identitas yang dibangun pada dunia maya sebenarnya bukan yang sesungguhnya. Sebab, mereka telah masuk pada dunia penuh dengan pencitraan.

Namun, dunia itu dipandang sebagai dunia nyata bagi mereka. Fakta yang tampak adalah bahwa seakan-akan terdapat gerakan serentak dan massal yang mengarah pada perubahan identitas ini. Pada awalnya, hal ini adalah perubahan serentak pada model pakaian yang dikenakan berdasarkan yang mereka tiru. 
Proses yang demikian dapat dicontohkan dengan peniruan gaya seperti berikut ini. Pada mulanya, mereka cenderung mengenakan pakaian yang sedang tren pada masa kini dengan berkiblat dari para artis. Kemudian, mereka mengikuti accessories, seperti tas. Tas-tas yang dimiliki para selebritas di ibu kota atau "papan atas" ini tentu tidak mudah dijangkau untuk seluruh kalangan. Sebagai akibatnya, di pasaran, ada tas serupa dengan merk dan kualitas berbeda. Hal ini bertujuan agar dapat dijangkau oleh semua kalangan dan diproduksi secara massal. Hal ini tentu menghancurkan nilai suatu barang yang ekslusif.

Namun, zaman sekarang ini, tuntutan kebutuhan pasar memang menghadirkan barang-barang tiruan. Adanya smartphone, hal itu semakin memudahkan semua orang untuk memiliki barang-barang tersebut. Akhirnya, semua masuk pada budaya popular masa kini yang diistilah dengan "barang-barang KW". Para konsumen yang menginginkan barang-barang itu menjadi gila belanja agar dapat terlihat ekslusif seperti idola mereka. Namun, mereka mengabaikan nilai fungsi suatu barang. Akhirnya, kondisi ini membuat mereka memiliki gaya hidup yang menganggap kemewahan bagian dari kebahagiaan. Hal ini merupakan fenomena budaya konsumerisme.

Budaya konsumerisme telah membuat para konsumen membeli segala sesuatu bukan berdasarkan kebutuhan, melainkan karena keinginan. Kemudahan mendapatkan barang itu sebagai contohnya melalui aplikasi pada genggaman mereka. Hal ini membuat semakin langgengnya budaya ini. Ketika satu produk dilempar ke pasaran, hal itu menjadi tren. Sebagai akibatnya, keadaan itu semakin mudah untuk mendapatkannya, terutama secara online.

Akhirnya, secara perlahan, identitas keaslian mereka telah tergerus karena hanya ingin mengikuti tren saja. Citra yang mereka tampilkan adalah citra bayangan. Hal ini disebut dengan identitas palsu. Identitas palsu itu semakin langgeng ketika ada pengakuan atas esksitensi dari ruang sosial mereka. Ruang sosial yang ada sekarang juga merupakan ruang 
sosial bentukan . Jadi, dia bukan ruang sosial yang real atau alamiah seperti dulu.

Kemunculan identitas palsu ini merupakan bagian dari krisis identitas. Hal ini tidak dapat ditemukan keaslian dan yang palsu. Sebab, ada banyak kepalsuan yang muncul. Sebagai homo ludens, mereka suka bermain-main. Akibtanya, mereka terbawa pada pembawaan identitas karena identitas tidak lagi dianggap penting. Kecenderungan meniru gaya selebritas ibukota lebih utama karena adanya anggapan yang memiliki gaya hidup seperti mereka adalah termasuk kelas atas.

Fakta ini memberikan petunjuk bahwa secara tidak sadar masyarakat terhegemoni oleh simbol-simbol semata. Setelah barang-barang yang ditiru, mereka kemudian meniru tingkah laku dan kebiasaan. Fenomena sekarang ini, banyak para pelajar meniru tingkah polah para selebritas. Mereka tidak memikirkan dampak ataupun manfaatnya. Mereka cenderung meniru agar terlihat seperti orang lain yang terkenal. Mereka tidak memahami kemanfaatan smartphone itu sendiri. Bagi pekerja, smartphone sangat penting. Sebab, selain untuk berkomunikasi, mereka menggunakan fitur-fitur dalam smartphone untuk membantu pekerjaan mereka. Kondisi ini bertolak belakang dengan para pelajar dan ibu rumah tangga.

Manusia bukan lagi hidup karena mereka berpikir. Namun, mereka hidup karena meniru. Identitas yang tidak jelas didukung oleh keberadaan smartphone dapat melanggengkan eksistensinya. Sebagai media baru, keberadaannya membuat tatanan moralitas mulai terpinggirkan. Moralitas dinomorduakan karena segala tindakan lebih mengutamakan untuk menuruti hidup yang penuh kesenangan. Jika lebih parah, hal itu menimbulkan suatu kepanikan moral. Sebab, hal itu memiliki kaitan erat dengan media dan kontrol sosial (McRobbie, 2014, h.344). Ketika tatanan moralitas telah terjadi suatu paradoks, hal itu menimbulkan chaos. Apalagi, jika hal itu berkaitan dengan identitas palsu antara nyata dan maya berbeda, keadaan tersebut memicu terjadinya chaos identitas. 


\section{Benteng Pertahanan Identitas}

Banyak orang yang aktif pada jejaring media social. Sebagai akibatnya, mereka menjadi pasif di dunia nyata. Hal tersebut tidak sedikit pula yang membuat akunakun palsu. Tujuannya adalah agar di dunia maya mereka memiliki banyak followers. Pembuat akun-akun palsu ini tidak hanya sebatas memiliki banyak pengikut, tetapi mereka memiliki motivasi tindakan untuk mendapatkan modal simbolik. Bagi dirinya yang bukan public figure atau artis, demi mencapai popularitas, mereka merepresentasikan dirinya sebaik mungkin dengan pencitraan.

Pencitraan ini dianggap dapat memberikan modal simbolik. Bordieu (dalam Lubis, 2014, h.120) menyatakan bahwa modal simbolik dapat memberikan suatu kuasa (kekerasan) dalam ruang sosial bahkan yang dikonstruksi selera dan kecantikan. Keadaan tersebut seperti yang ingin dicapai oleh mereka yang mempermainkan citra dalam dunia sosial.

Secara tidak sadar, sebenarnya, hal ini menyebabkan krisis identitas. Sejatinya, manusia itu memang harus memiliki identitas yang saling terkait antara dunia nyata dan maya. Sebab, hal ini menunjukkan representasi jati dirinya.

Selama ini, keasyikan dalam dunia maya membuat mereka lupa bahwa dunia yang sebenarnya harus dihadapi adalah dunia nyata. Mereka telah hidup di dunia hiper-realitas. Mereka sudah jauh dari realitas yang ada. Hiperealitas tidaklah diproduksi, tetapi siap diproduksi (Baudrillard dalam Lubis, 2014, h.185). Komunikasi yang mereka lakukan sudah teralihkan dalam dunia maya. Akibatnya, hal itu tidak mengherankan bila banyak orang yang bersifat individualistis. Kini, orang jarang bertegur sapa atau sekedar mengajak berbicara, seperti contohnya di kendaraan umum. Mereka yang duduk di sebelahnya telah sibuk dengan dunianya sendiri. Sifat individualistis ini membuat mereka mengalienasikan diri dengan dunia luar karena kesibukan aktif dalam dunia maya.

Untuk mengatasi keadaan tersebut, pencegahannya adalah dengan mengembalikan ruang-ruang sosial yang ada pada dunia nyata. Berhubungan dengan orang lain tidak 
sekedar untuk berkomunikasi saja, tetapi juga dapat menunjukkan kepedulian dan simpati pada orang lain. Maka dengan begitu, orang akan terasah dan moralitas menjadi pegangan dalam hidup. Sebagai makhluk sosial, nada kepekaan sosial dikembalikan agar tidak bersifat individualistis.

Pembatasan penggunaan smartphone juga penting untuk dilakukan agar tepat guna. Benteng utama dari identitas adalah diri pribadi. Karakter diri perlu diperkuat agar tidak mudah terbawa arus. Representasi identitas yang ditunjukkan sudah semestinya termanifestasikan dalam seluruh kehidupan.

\section{SIMPULAN}

Teknologi pada kehidupan manusia memiliki pengaruh yang besar. Salah satunya adalah teknologi komunikasi. Sebelum mengenal komunikasi, manusia memiliki interaksi sosial yang baik dengan sesama. Mereka masih memiliki nilainilai komunal yang kuat. Namun, seiring perkembangan zaman dan kemajuan teknologi, nilai-nilai komunal ini mulai luntur dan tergantikan dengan individualistis.
Semua orang sibuk dengan dunianya sendiri, dalam dunia mayanya, melalui akun-akun media sosialnya. Media sosial yang terdiri dari berbagai macam produk merupakan bagaian dari budaya popular masyarakat era abad ke-21 ini.

Simpulan dari penelitian ini adalah perubahan ini menyebabkan manusia memiliki identitas palsu. Identitas palsu ini menimbulkan chaos identitas sebab terjadi paradoks antara dunia nyata dan dunia maya yang menimbulkan degradasi moral. Representasi semu yang ditampilkan dalam dunia maya bertolak belakang dengan kehidupan nyata, yaitu dengan memiliki identitas lain alam dunia maya. Mereka hidup dalam dunia simulacrum yang penuh dengan hiper-realitas. Akibatnya, sesuatu yang muncul penuh dengan kepalsuan. Hal ini menyebabkan krisis identitas sebab identitas yang ditampilkan adalah palsu. Kepalsuan identitas ini merupakan suatu kondisi chaos yang harus ditangani agar dapat membentuk pribadi yang utuh. Sebab, mereka sesungguhnya terjebak dalam dunia simulakra. Maka, penguatan identitas sangat 
diperlukan agar terbentuk identitas nyata dalam kehidupan nyata dan dunia maya. Media social telah memberikan ruang-ruang sosial dan membatasi penggunaan smartphone.

\section{Ucapan Terima Kasih}

Terima kasih pada LPDP RI yang telah memberikan batuan dana penelitian ini.

\section{DAFTAR PUSTAKA}

Budiawan (Ed). 2015. Media (Baru), tubuh, dan ruang publik. Yogyakarta: Jalasutra.

Featherstone, M. (2008). Posmodernisme dan budaya konsumen. Yogyakarta: Pustaka Pelajar.
Frissen, V. (et.al). (2015). Playful identities: the ludification of digital media cultures. Amsterdam: Amsterdam University Press.

Ida, R. (2014). Metode penelitian studi media dan kajian budaya. Jakarta: Prenada Media Grup.

Lubis, A.Y. (2014). Postmodernisme: teori dan metode. Jakarta: PT. Rajagrafindo Persada.

Lubis, A.Y. (2015). Pemikiran kritis kontemporer. Jakarta: PT. Rajagrafindo Persada.

McCarthy, T. (2015). Teori kritis Jürgen Habermas (perjemah: Nurhadi). Yogyakarta: Kreasi Wacana.

McRobbie, A. (2014). Posmodernisme dan budaya pop (penerjemah: Nurhadi). Yogyakarta: Kreasi Wacana.

Peursen, C.A.V. (1988). Strategi kebudayaan. Yogyakarta: Kanisius. 